M. M. MATURI, T. BACH* (TECHNISCHE UNIVERSITÄT MÜNCHEN, GARCHING, GERMANY) Enantioselective Catalysis of the Intermolecular [2+2] Photocycloaddition between 2-Pyridones and Acetylenedicarboxylates

Angew. Chem. Int. Ed. 2014, 53, 7661-7664.

\section{Catalytic Enantioselective [2+2] Intermolecular Photocycloaddition}<smiles>[R]OC(=O)C#C[C+]C(=O)O[Na]</smiles><smiles>[R20]OC(=O)C1=C([R20])[C@@]2([R17])C=CC(=O)N[C@H]12</smiles>

$$
\mathrm{R}^{1}=\mathrm{H}, \mathrm{Me}
$$$$
\mathrm{R}^{2}=\mathrm{Me}, \mathrm{Et}, t-\mathrm{Bu}
$$

HFX: hexafluoro $m$-xylene TFT: trifluorotoluene

\section{Selected examples:}<smiles>CCOC(=O)C1=C(C(=O)OCC)C2NC(=O)C=CC12</smiles><smiles>CCOC(=O)C1=C(C(=O)OCC)C2(C)NC(=O)C=CC12</smiles>

$65 \%$ yield er $=79.5: 20.5$

\section{$53 \%$ yield} er $=94: 6$<smiles>CC(=O)C1=C(C(C)=O)C2(C)C=CC(=O)NC12</smiles><smiles>CC1=C[C@H]2C(C(=O)OC(C)(C)C)=C(C(=O)OC(C)(C)C)[C@H]2NC1=O</smiles>

$88 \%$ yield er $=86: 14$

$76 \%$ yield er $=95: 5$

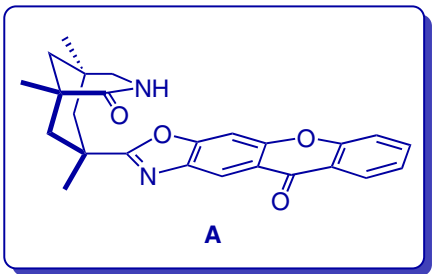

Proposed catalyst-substrate interaction:

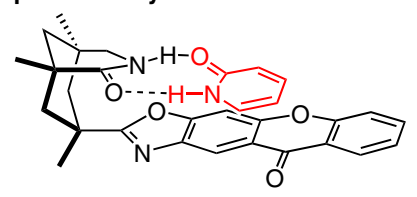

Key words

hydrogen-bonding catalysis

[2+2] photocycloaddition

photochemistry

photosensitizer

SYNFACTuth of the mont
Significance: Maturi and Bach report the first metal-free catalytic, enantioselective intermolecular [2+2] photocycloaddition. The studied model reaction between 2-pyridones and diester alkynes is catalyzed by the chiral triplet sensitizer $\mathbf{A}$, which coordinates 2-pyridones via hydrogen bonding. This interaction accounts for enantioface differentiation of the excited complex and decreased substrate-sensitizer dissociation, which would result in non-enantioselective pathways. Moderate to excellent enantioselectivities and acceptable to good yields were obtained for the corresponding cycloadducts at low catalyst loadings (2.5-5 mol\%).
Comment: The Bach group continues to contribute significantly to the challenging field of enantioselective, catalytic photochemistry. Their approach of using chiral photosensitizers, which are able to bind the substrate via hydrogen bonds, already proved to be successful in their previous studies on intramolecular [2+2] photocycloadditions (J. Am. Chem. Soc. 2011, 133, 16689). They now show that the intermolecular process can also be accomplished in a catalytic, asymmetric fashion. Although in some cases only moderate enantiocontrol and yields were obtained, the comparably low catalyst loading highlights the high efficiency of their strategy. Thus, further improvement of enantioselectivity and substrate compatibility is expected for the near future.

SYNFACTS Contributors: Benjamin List, Tim Gatzenmeier Dol: 10.1055/s-0034-1378656; Reg-No.: B06814SF 